\title{
IRON DEFICIENCY ANEMIA, SERUM IRON IN CHILDREN WITH BRONCHIAL ASTHMA
}

\author{
Wagdy A. Elsayed and Eman Essa \\ Department of Pediatric and Clinical Pathology, Banha teaching hospital
}

\author{
Corresponding Author: \\ Wagdy A. Elsayed \\ Email: \\ wagdyattia@yahoo.com
}

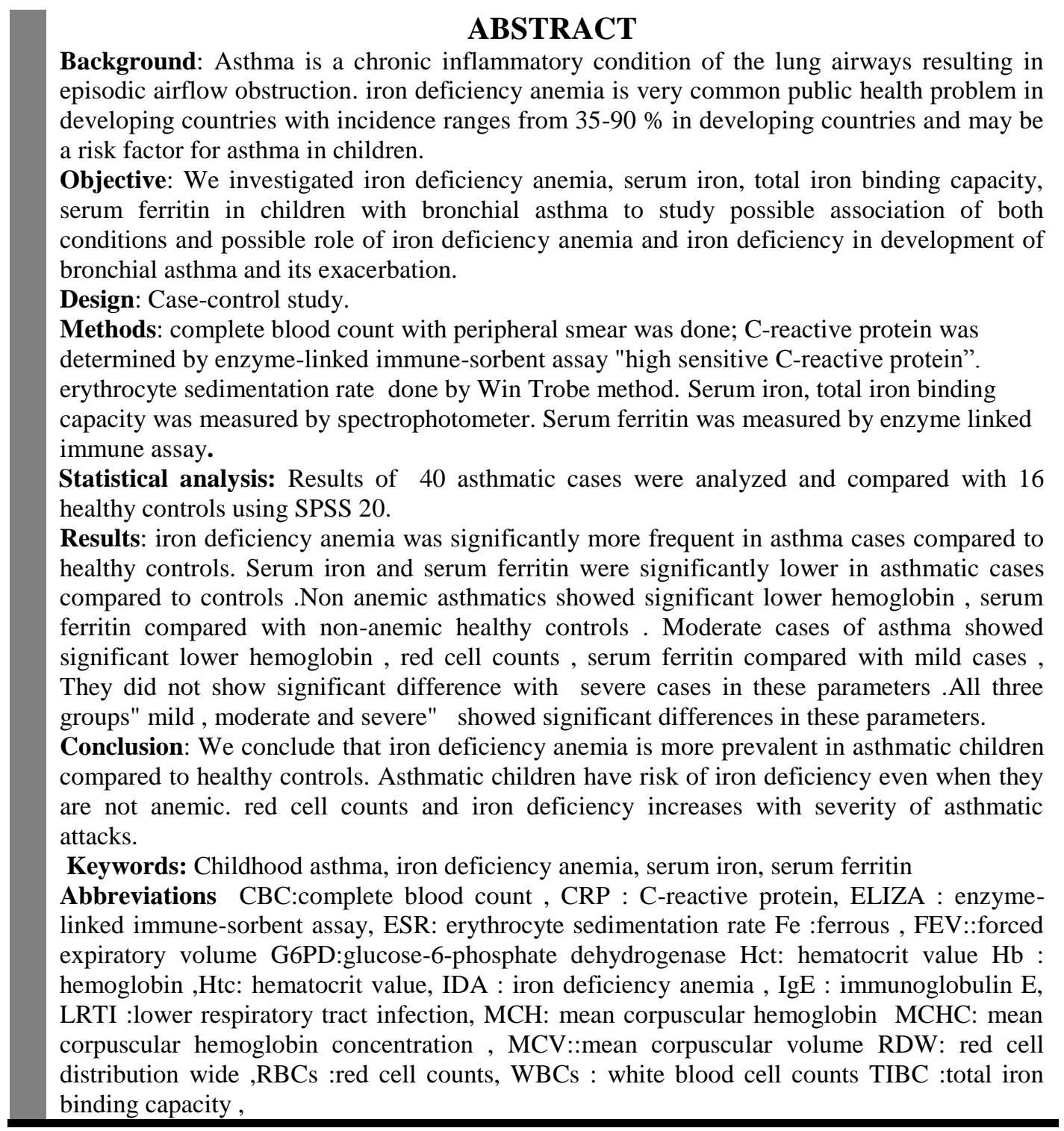

\section{1- INTRODUCTION \& OBJECTIVE}

A sthma is a chronic inflammatory condition of the lung airways resulting in episodic airflow obstruction. Different etiological factors including genetic, environmental factors are involved in development of asthma .(1) Among risk factors for asthma exacerbation : infection, Allergen exposure, non-use of controller medication, non -white race and winter season (2). Dietary factors are implicated in development of asthma in children as well as adults.
Iron deficiency anemia (IDA) is i the most common nutritional disorder in the world especially Eastern Mediterranean Region The prevalence of anemia was found to be especially high among children from low socioeconomic groups who live in crowded environments and prone to recurrent infections.(3)

Few reports described association between anemia and bronchial asthma (4). Anemia has been shown to be a risk factor for lower respiratory tract infection (LRTI), []ㅡ and asthma( 
6) Maternal anemia was found to be associated with increased risk of wheezes and asthma in children (7)

The relation of anemia to atopic diseases has been studies in some reports. Drury st al 2014 (8) found association of eczema, asthma , food allergy with anemia particularly microcytic hypochromic anemia . Whether anemia is the result of chronic inflammation associates atopy or it risk factor of atopic diseases .This needs further investigation

Iron has variable role regarding asthma and respiratory function. Some reports described iron as free radicle and potentially toxic, impair pulmonary function, and potentiate asthma (9).

On other hand, iron is component of cellular enzyme with respiratory function, hemoglobin and myoglobin, its deficiency (ID) may impair respiratory function and associate asthma development (10) .Some reports described anti allergic role of iron in experimental animals. Iron deficiency was identified as a trigger for increased mast cell activation that was associated with mast cell-dependent hair loss in IL-10deficient mouse pups [11] Maazi H.et al 2011 (12)found that iron administration reduces airway hyper reactivity and eosinophilia in a mouse model of allergic asthma. Another study by Hale et al 2012(13) found that iron supplemented diet decreased severity of allergic inflammation in murine lung. Desferrioxamine (iron chelating agent) treatment suppresses significantly immunoglobulin $\mathrm{E}$ ( $\mathrm{IgE}$ ) production and lymph proliferation, and possibly Th2-dominated autoimmune syndrome (14). Inverse associations were found between maternal serum ferrous ( $\mathrm{Fe}$ ) status at delivery and childhood atopic outcomes including wheezing and eczema (15).

For possible role of serum iron state and iron deficiency anemia in development and management of asthma in children we investigated serum iron, ferritin and iron deficiency anemia in children with bronchial asthma

\section{2-SUBJECTS\&METHODS}

Patients group: 40 children diagnosed as bronchial asthma with age ranged from $24-101$ months wasi chosen from pediatric department in Banha Teaching Hospital. Detailed history, physical examination was done for all cases.
Diagnosis of asthma based on history of recurrent acute attack of cough, dyspnea and wheezes in child more than 2 years in response to provocation which is associated with impaired lung function " in 6ys or older " and improved with bronchodilator $\beta$ agonist in addition to family history and eosinophilia. Respiratory function (FEV) was assessed in children older than 6 years in absence of other causes of wheezing (6)

Acute attack of asthma was classified as: 1-mild presented with mild distress only with excretion, end expiratory wheeze, pulse 100/minute, $\mathrm{O}_{2}$ saturation >95\%. 2-moderate presented with distress on rest with difficult feeding , loud whole expiratory wheezes pulse rate 100-120/minute, $\mathrm{O}_{2}$ sat 90-95 3-severe distress on rest stop feeding ,loud wheezes expiratory, inspiratory, pulse > 120 /minute , $\mathrm{O}_{2}$ saturation $<90 \%$ (1)

Anemia was defined as reduction in hemoglobin level, hematocrit or number of red blood cells per cubic millimeter below the lower limit of the normal range is set at two standard deviations below the mean for age and sex for the normal population " below $10.5 \mathrm{gm} / \mathrm{dl}$ at $0.5-2$ years age ,below $11.5 \mathrm{gm} / \mathrm{dl}$ at 2-12ys age " $(16,17)$

Exclusion criteria cases with possible causes of wheezes other than asthma as congenital lung lesion, reflex disease, cardiac, chest diseases other than asthma, possible immune deficiency evidence of bacterial infection, parasitic infestations and, wheezes in first time were excluded from the study. Those with family history suggested hemolytic anemia as G6PD deficiency and thalassemia were excluded .Also cases with severe other systemic illness, protein energy malnutrition, known hematological diseases other than IDA, children on iron medication for 30 days prior to sample collection, and children with a history of prematurity or low birth weight were also excluded .

The control group: were selected from 1ry health care center coming for routine care as immunization, complains not suggesting bacterial infections, infestation, allergy, or chest diseases. Those with history suggest hematological or respiratory illness in last one month or any history 
suggest asthma or recurrent cough were excluded.

- Those who showed pallor, chest or hematological problem on examination were excluded. In addition, those with family history suggest asthma or atopic diseases were excluded.

\section{Laboratory and radiological investigations:}

Laboratory investigations including $\mathrm{CBC}$ with peripheral smear was done, CRP was determined by ELIZA "high sensitive CRP". ESR done by Win Trobe method. Serum iron, total iron binding capacity was measured by spectrophotometer. Serum ferritin was measured by enzyme linked immune assay kits provided from immune spec cooperation 7018 Owens mouth Ave. suit *103 Cango Bank ,C.A .91303 ).Also stool analysis done routinely for cases and controls

Blood sampling: Three mls of blood were taken at 24 hours of age from both cases and controls and left for 20 minutes at $37 \mathrm{C}^{\circ}$. Serum was separated after centrifugation and kept at -20 $\mathrm{C}^{\mathrm{O}}$ until analysis.

\section{Principle of measurement of serum ferritin:}

The test is based on solid phase enzymelinked immune-sorbent assay (IELIZA) .The assay system utilizes anti ferritin antibody for solid phase ( microliter wells)immobilization and another mouse anti- ferritin antibody in the antibody-enzyme(horseradish peroxidase ) conjugate solution. The test sample is allowed to react simultaneously with the antibodies resulting in ferritin molecules being sandwiched the solid phase and enzyme -linked antibodies is added after the wells are washed, resulting in the development a blue color.

The concentration of ferritin was directly proportional to the color intensity of the test sample

Radiological investigations : chest $\mathrm{x}$ ray

was done routinely for all cases included in the study, C. T. scan was done for cases suspected to have another causes of wheezing other than asthma

Legal aspect: Written consents have been taken from the parents of all the children included in this study. The study also was approved from the Research Ethics Committee in General Organization for Teaching Hospital and Institutes in Cairo.
Statistical Analysis: Data were analyzed using SPSS 20 computer program (IBM, Endicott, Broome County, New York, United States). Data were expressed as mean \pm SD for categorized variables. Tests of significance "Chisquare and T tests" and correlation study were done where appropriate $\mathrm{P}<0.05$ was statistically significant.

\section{3-RESULTS}

The study included 55 children 38 cases diagnosed as bronchial asthma, 15 healthy children taken as controls No significant statistical differences between cases and controls regarding age,sex and weight ( $\mathrm{P}$ was 0.959 , 0.655 and 0.212 respectively)."Table $1 "$

\section{Clinical characteristics of patients group:}

Among 40 cases of asthma, 8 cases (20\%) presented with mild acute attack, 22 cases $(55 \%)$ moderate acute attack and $10(25 \%)$ cases presented in severe acute attack. None of as asthma cases showed evidence of bacterial infection clinically or laboratory. 12 cases had naso pharyngitis with low-grade fever 5 cases had naso-pharyngitis without fever. Most cases with fever without rhinorrhea showed clinical and laboratory evidence of bacterial infection and were excluded "Table 2" None of cases or controls showed evident clinical manifestation of anemia

\section{Laboratory parameters of the patient and controls:}

Asthma cases showed lower $\mathrm{Hb}$,Hct , $\mathrm{MCH}, \mathrm{MCHC}, \mathrm{MCV}$, serum iron ,TIBC ,serum ferritin compared ${ }_{0}$ controls $(\mathrm{P}$ was $0.000,0.000,0.000,0.013,0.000 \quad, 0.000,0.000$ respectively). 25 of $(62.5 \%)$ asthma cases had $\mathrm{Hb}$ level in range of anemia according to previous definition of anemia-compared to 7 of 15 controls (46.66 \%) (P was 0.000 by chi-square test). None of asthma cases showed serum ferritin below 12 $\mathrm{mg} / \mathrm{dl}, 5$ showed serum ferritin below $20 \mathrm{ng} / \mathrm{dl}$. Most anemic cases and controls showed feature of IDA (high TIBC, high RDW, low serum ferritin)

Asthma cases showed higher ESR compared to controls ( $\mathrm{P}$ was 0.000) .No significant differences between cases and controls regarding RBCs, RDW, WBCs and platelets ( $\mathrm{P}$ was $\quad 0.179, \quad 0.072, \quad 0.059$ and $\quad 0.295$ respectively).All asthma cases and controls selected had -ve CRP. "Table 3" .Non anemic 
cases did not show significant differences with controls regarding $\mathrm{RBC}$, serum iron, Htc, $(\mathrm{P}$ : $0.351,0.264$ and 0.659 respectively), while showed lower $\mathrm{Hb}$, serum ferritin (P: $0.001,0.000$ respectively) and higher TIBC (P:0.000) " data not shown"

Clinical data relation to with $\mathrm{Hb}, \mathrm{RBCs}$, Iron status:

Asthmatic cases who had fever did not show significant differences with those without fever regarding $\mathrm{Hb}, \mathrm{RBCs}$, serum iron ,TIBC and serum ferritin ( $\mathrm{P}$ was $0.679,0.81,0333,0.361$ and 0.993 respectively). Also cases with nasopharyngitis showed no significant difference with those without naso pharyngitis regarding these parameters $(\mathrm{P}$ was $0.451,0.778,0.22$, 0.123 and 0.262 "Table 4"

Moderate cases of asthma showed lower $\mathrm{Hb}, \mathrm{RBCs}$, serum ferritin relative to mild cases $(\mathrm{P}$ was $0.000,022$, and 0.002, respectively). They showed higher TIBC relative to mild cases (P was 0.005). No significant differences between moderate and mild cases regarding serum iron ( $\mathrm{P}$ was 0.149). No significant statistical differences between severe and moderate cases in $\mathrm{Hb}$,
RBCs, serum iron, TIBC and serum ferritin ( $P$ was $0.543,0.941,0.394,0.980$ and 0.731 , respectively) "data not shown ". All the 3 groups "mild , moderate and severe" showed significant differences in means in $\mathrm{Hb}, \mathrm{RBCs}$, TIBC and serum ferritin using "one way ANOVA" ( $\mathrm{P}$ was $0.002,0.043,0.009$ and 0.003 ) with no difference in serum iron P was 0.341) "table 4"

Clinical data, serum ferritin :correlation with $H b, R B C s$, iron status :

No significant correlation found between age or weight with $\mathrm{Hb}, \mathrm{RBC}$,serum iron, TIBCs and serum ferritin ."Table 5"

No significant correlation found between age or weight with duration of admission ( $\mathrm{P}$ was $0.779,0.142$ ) "data not shown"

Significant -ve correlation found between duration of admission and serum ferritin ( $\mathrm{P}$ was 0.009) "Table 5"

Serum ferritin had significant +ve correlation with, $\mathrm{Hb}$ and -ve correlation with TIBC $\mathrm{P}$ was $0.039,0.037$ respectively .No correlation was found with RBCs, Htc and serum iron

Table (1): Clinical Parameters in Patients, Controls

\begin{tabular}{|c|c|c|c|c|}
\hline & & Cases $n=40$ & Controls $n=15$ & $\mathrm{P}$ \\
\hline \multirow{2}{*}{ Age (months) } & $\ddot{\mathrm{X}} \pm \mathrm{SD}$ & $39.2 \pm 17.263$ & $38.73 \pm 21.049$ & \multirow{2}{*}{$0.959 \mathrm{NS}$} \\
\hline & Range & $24-101$ & $24-102$ & \\
\hline \multirow{2}{*}{ Sex } & Females & $16-40 \%$ & $7-47 \%$ & \multirow{2}{*}{$0.655 \mathrm{NS}$} \\
\hline & Males & $24-60 \%$ & $8-53 \%$ & \\
\hline \multirow{2}{*}{ Weight (kg) } & $\ddot{\mathrm{X}} \pm \mathrm{SD}$ & $14.5 \pm 3.445$ & $15 \pm 3.523$ & \multirow{2}{*}{$0.212 \mathrm{NS}$} \\
\hline & Range & $10-27$ & $13-26$ & \\
\hline
\end{tabular}

Table (2): Clinical data of the patients group

\begin{tabular}{ccccc}
\hline \multirow{2}{*}{ C inical data } & & Number & Frequencies \\
\hline \multirow{2}{*}{ Naso pharyngitis } & Fever & 12 & $30 \%$ \\
\cline { 2 - 4 } & No fever & 5 & $12.5 \%$ \\
\hline \multirow{2}{*}{ Fever } & +ve & 12 & $30 \%$ \\
\cline { 2 - 4 } & -ve & 28 & $70 \%$ \\
\cline { 2 - 4 } Severity of attack & Mild & 8 & $20 \%$ \\
\cline { 2 - 4 } & moderate & 22 & $65 \%$ \\
\cline { 2 - 4 } & Severe & 10 & $25 \%$ \\
\hline
\end{tabular}


Table (3): Cases versus controls regarding the laboratory data

\begin{tabular}{|c|c|c|c|c|}
\hline Laboratory & & Cases $=40$ & Controls $=15$ & $\mathbf{P}$ \\
\hline \multirow{4}{*}{$\mathrm{Hb}(\mathrm{gm} / \mathrm{dl})$} & $\ddot{\mathrm{X}} \pm \mathrm{SD}$ & $10.30 \pm 1.366$ & $12.02 \pm 1.1 .05$ & \multirow{2}{*}{$0.000 \mathrm{HS}$} \\
\hline & Range & $8-13$ & $10-14$ & \\
\hline & \multirow{2}{*}{ Anemia } & +ve $25(62.5 \%)$ & +ve $7(46.66 \%)$ & \multirow{2}{*}{$0.000 \mathrm{HS}$} \\
\hline & & -ve $15(37.5 \%)$ & -ve $8(53.34 \%)$ & \\
\hline \multirow{2}{*}{$\operatorname{Hct}(\%)$} & $\ddot{\mathrm{X}} \pm \mathrm{SD}$ & $32.6 \pm 6.09$ & $36.8 \pm 2.08$ & \multirow{2}{*}{$0.000 \mathrm{HS}$} \\
\hline & Range & $22-47$ & $33-40$ & \\
\hline \multirow{2}{*}{$\operatorname{RBCs}\left(\times 10^{6}\right)$} & $\ddot{\mathrm{X}} \pm \mathrm{SD}$ & $4.19 \pm 0.884$ & $4.43 \pm 0.386$ & \multirow{2}{*}{$0.179 \mathrm{NS}$} \\
\hline & Range & $2.3-6.22$ & $3.8-5.1$ & \\
\hline \multirow{2}{*}{$\mathrm{MCH}$} & $\ddot{\mathrm{X}} \pm \mathrm{SD}$ & $22.455 \pm 3.06$ & $26.8 \pm 1.96$ & \multirow{2}{*}{$0.000 \mathrm{HS}$} \\
\hline & ange & $17-27$ & $24-30$ & \\
\hline \multirow{2}{*}{$\mathrm{MCHC}$} & $\ddot{\mathrm{X}} \pm \mathrm{SD}$ & $29.97 \pm 2.87$ & $32.08 \pm 2.246$ & \multirow{2}{*}{$0.013 \mathrm{~S}$} \\
\hline & Range & $22-35$ & $25-34$ & \\
\hline \multirow[t]{2}{*}{$\mathrm{MCV}$} & $\ddot{\mathrm{X}} \pm \mathrm{SD}$ & $\begin{array}{c}70.295 \pm 7.94 \\
295 \pm 7.94 \\
\end{array}$ & $78.726 \pm 3.257$ & \multirow[t]{2}{*}{$0.000 \mathrm{HS}$} \\
\hline & Range & $61-87$ & $73-85$ & \\
\hline \multirow{2}{*}{ RDW } & $\ddot{\mathrm{X}} \pm \mathrm{SD}$ & $14.02 \pm 1.424$ & $13.25 \pm 1.308$ & \multirow{2}{*}{0.072} \\
\hline & Range & $12-16$ & $11.5-15$ & \\
\hline \multirow{2}{*}{ WBCs $\left(\times 10^{3}\right)$} & $\ddot{\mathrm{X}} \pm \mathrm{SD}$ & $8.855 \pm 2.782$ & $7.724 \pm 1.481$ & \multirow{2}{*}{$0.059 \mathrm{NS}$} \\
\hline & Range & $5-15.4$ & $5.060-11000$ & \\
\hline \multirow{2}{*}{ Platelets $\left(\times 10^{3}\right)$} & $\ddot{\mathrm{X}} \pm \mathrm{SD}$ & $3.339 \pm 1.52$ & $3.76 \pm 0.966$ & \multirow{2}{*}{$0.295 \mathrm{NS}$} \\
\hline & Range & $110-650$ & $250-560$ & \\
\hline $\mathrm{CRP}(\mathrm{mg} / \mathrm{dl})$ & & -ve & -ve & \\
\hline \multirow{2}{*}{ ESR } & $\ddot{\mathrm{X}} \pm \mathrm{SD}$ & $19.87 \pm 5.82$ & $9.9 \pm 2.48$ & \multirow{2}{*}{$0.000 \mathrm{HS}$} \\
\hline & Range & $10-30$ & $5-15$ & \\
\hline \multirow{2}{*}{ Serum iron $\mathrm{mg} / \mathrm{dl}$} & $\ddot{\mathrm{X}} \pm \mathrm{SD}$ & $77.375 \pm 32.2$ & $118 \pm 23.05$ & \multirow{2}{*}{$0.000 \mathrm{HS}$} \\
\hline & Range & $20-160$ & $80-150$ & \\
\hline \multirow{2}{*}{ TIBC } & $\ddot{\mathrm{X}} \pm \mathrm{SD}$ & $370.5 \pm 31.29$ & $288.666 \pm 15.31$ & \multirow{2}{*}{$0.000 \mathrm{HS}$} \\
\hline & Range & $320-420$ & $260-320$ & \\
\hline \multirow{2}{*}{ Serum ferritin $\mathrm{mg} / \mathrm{dl}$} & $\ddot{\mathrm{X}} \pm \mathrm{SD}$ & $40.66 \pm 24.733$ & $92.53 \pm 21.922$ & \multirow{2}{*}{$0.000 \mathrm{HS}$} \\
\hline & $\mathrm{R}$ nge & $13-90$ & $60-130$ & \\
\hline
\end{tabular}


Table (4) Clinical data relation to with $\mathrm{Hb}, \mathrm{RBCs}$, Iron status

\begin{tabular}{|c|c|c|c|c|c|c|}
\hline & & $\mathrm{Hb}$ & $\mathrm{RBCs}$ & Iron & TIBC & $\begin{array}{c}\text { Ferritin } \\
\text { FFFFerritin }\end{array}$ \\
\hline \multirow{4}{*}{ Fever } & $+\mathrm{ve}$ & $10.16 \pm 1.3$ & $4.14 \pm 0.67$ & $85 \pm 34.77$ & $377.5 \pm 29.87$ & $43.93 \pm 27.174$ \\
\hline & -ve & $10.36 \pm 1.42$ & $4.21 \pm 0.97$ & $74.11 \pm 31.12$ & $367.50 \pm 31.93$ & $39.26 \pm 24$ \\
\hline & $\mathrm{P}$ & 0.679 & 0.81 & 0.333 & 0.361 & 0.591 \\
\hline & $+\mathrm{ve}$ & $10.14 \pm 1.28$ & $4.14 \pm 0.7$ & $84.7 \pm 37.93$ & $379.4 \pm 30.09$ & $37.55 \pm 24.9$ \\
\hline \multirow{2}{*}{$\begin{array}{c}\text { Acute } \\
\text { naspharyngitis }\end{array}$} & -ve & $10.41 \pm 1.44$ & $4.23 \pm 1.01$ & $71.96 \pm 26.8$ & $363.9 \pm 31.15$ & $42.96 \pm \mathbf{2 4 . 9 0 5}$ \\
\hline & $\mathrm{P}$ & 0.541 & 0.778 & 0.22 & 0.123 & 0.502 \\
\hline \multirow{5}{*}{$\begin{array}{l}\text { Asthma } \\
\text { severity }\end{array}$} & Mild & $11.74 \pm 1.126$ & $4.88 \pm 0.885$ & $89.38 \pm 24.56$ & $341.25 \pm 25.88$ & $65.86 .86 \pm 25.433$ \\
\hline & Moderate & $9.85 \pm 1.146$ & $4.03 \pm 0.86$ & $70.91 \pm 31.76$ & $377.73 \pm 29.75$ & $35.22 \pm 20.507$ \\
\hline & Severe & $10.13 \pm 1.294$ & $4.00 \pm 0.76$ & $82 . \pm 37.65$ & $378 \pm 26.58$ & $32.47 \pm 21.33$ \\
\hline & F"ANOVA" & 7.64 & 3.431 & 1.108 & 5.341 & 6.787 \\
\hline & $\mathrm{P}$ & 0.002 & 0.043 & 0.341 & 0.009 & 0.003 \\
\hline
\end{tabular}

Table (5): Clinical data, serum ferritin correlation with $\mathrm{Hb}, \mathrm{RBCs}$, iron status

\begin{tabular}{|c|c|c|c|c|}
\hline & Age & Weight & $\begin{array}{l}\text { Duration Of } \\
\text { Admission }\end{array}$ & $\begin{array}{l}\text { Serum } \\
\text { ferritin }\end{array}$ \\
\hline \multirow[b]{2}{*}{$\mathrm{Hb}(\mathrm{gm} / \mathrm{dl})$} & $\mathrm{R}: 0.025$ & 0.033 & 0.089 & 0.328 \\
\hline & P: 0.876 & 0.84 & 0.584 & 0.039 \\
\hline \multirow[b]{2}{*}{$\operatorname{Hct}(\%)$} & R: 0.107 & 0.092 & $-0.187-$ & 0.231 \\
\hline & P: 0.513 & 0.574 & 0.248 & 0.152 \\
\hline \multirow[b]{2}{*}{$\mathrm{RBCs}$} & R: 0.066 & 0.189 & $-0.169-$ & 0.243 \\
\hline & P: 0.163 & 0.242 & 0.296 & 0.8131 \\
\hline \multirow[b]{2}{*}{ Serum iron $\mathrm{mg} / \mathrm{dl}$} & R 0.128 & 0.031 & 0.024 & 0.040 \\
\hline & P 0.43 & 0.849 & 0.884 & 0.804 \\
\hline \multirow[b]{2}{*}{ TIBC } & R-.119- & 0.105 & 0.034 & 0.332 \\
\hline & P 0.464 & 0.517 & 0.833 & 0.037 \\
\hline \multirow{2}{*}{ Serum ferritin } & R 0.209 & 0.251 & $-0.407-$ & 1 \\
\hline & P 0.197 & 0.118 & 0.009 & \\
\hline
\end{tabular}

\section{4- DISCUSSION}

In this study, we investigated iron deficiency and iron deficiency anemia as a possible risk factor for development of asthma and asthma exacerbation in children. Despite increased prevalence of asthma and iron deficiency anemia in children few reports available in this subject possible because of low incidence of IDA in developed countries (18).

We investigated 40 cases diagnosed as asthma to study their association with IDA in children with relatively low socioeconomic standard. In addition, serum ferritin is acute phase reactant and is expected to increase in cases with bacterial, parasitic infestations and inflammatory conditions (16). So we involved 15 children age, sex and weight matched as a control, also cases with evident bacterial, parasitic infection were excluded.

Despite our sample was not randomizes because of exclusion criteria and relative small size, the mean age, sex and 
weight may be representative and similar our previous report in the same locality (19). Similar result was found regarding age, sex distributions in Middle East area (6, 20, and 21)

Among asthma cases we found 25 of 40 $(62.5 \%)$ cases compared to 7 of $15(46.66 \%)$ controls has anemia $\mathrm{P}$ was 0.000 . Lower $\mathrm{Hb}$, Htc, MCV, MCHC, MCH lwas found in asthmatic cases to controls ( $\mathrm{P}$ was 0.000 , $0.000,0.000,0.013$ and 0.000 , respectively). These results indicate that hypochromic microcytic anemia is more prevalent in our asthma cases. Lower $\mathrm{Hb}$ in asthmatic cases compared to control was found in our previous report (19) Association of anemia with asthmatic children was found in other reports. Ramakrishnan K. et al 2010 (4) suggested that anemia is possible risk factor of asthma. They found that incidence of asthma in Indian anemic children was $74 \%$ compared to $33 \%$ of non-anemic controls with predominance of IDA (85\% of anemic asthmatics) .Eissa SA et al 2016 (22) found children with IDA has more risk of asthma (66 \%) compared to nonasthmatics (24\%) . ,Asthma is associated with intermittent or chronic inflammation and can cause anemia (116). Anemia of chronic inflammation is normochromic normocytic sometimes hypochromic microcytic due to altered iron metabolism to reticulo-endothelial system on expense of hem synthesis . Despite low serum iron, TIBC low and serum ferritin normal to high in this last type of anemia (23) .Other possible explanation of this association that anemia is risk factor for development of asthma and asthmatic attacks . In favor of this suggestion that previous reports about association of maternal anemia and development of wheezes and asthma in early childhood (24). Our results support this suggestion .Low serum iron ,ferritin and high TIBC in our asthma cases compared to controls ( $\mathrm{P}$ was $0.000,0.000$ and 0.000 respectively ) classify anemic asthmatics as IDA. .It was possible to find hypochromic microcytic anemic cases other IDA among our anemic cases if our sample was taken random. Because of strict exclusions criteria of cases with possible other causes of anemia for patients and controls, most anemic cases and controls were IDA. IDA can be risk factor of asthma rather than consequence. Anemia of chronic inflammation, which is possible consequence of asthma, has different laboratory feature IDA as mentioned before. Asthma in children has 2 phenotypes: 1-Transient non atopic type which start in preschool age, provoked by viral URTI, resolve by school age, inflammation not evident in this type. 2-Persistent atopy associated type which start in early preschool age ,associated with atopic manifestation ,elevated $\operatorname{IgE}$, provoked by allergen sensitization may, persist into late childhood .Inflammatory reaction is evident in this type (25). Most of our patients are of non-atopic transient phenotype of asthma where chronic inflammation is not present. The age distribution of IDA in developing countries comes parallel to age distribution of last phenol type (26). The association between IDA and childhood asthma can be explain by the role of maternal dietary factors in development of asthma, atopy in children. Maternal anemia (7) and low iron intake (27) was associated with increased risk of wheezing, atopy in children. Despite normal iron level in infants born to mothers with iron deficiency, the levels are typically lower than those in infants born to non-anemic mothers (28), iron stores may be depleted before 6 months (29), and IDA can continue to postnatal life .Socioeconomic factors, which contribute to anemic mother possibly, contribute to anemic infants. Maternal anemia and low iron status during pregnancy was suggested to induce fetal lung programing (7) and affect fetal lung development in utero (30)

Anemia was suggested to be risk factor in exacerbation of asthmatic attacks because $\mathrm{Hb}$ facilitates oxygen $(\mathrm{O} 2)$ and carbon dioxide transport, it carries and inactivates nitric oxide (NO) and also plays the role of the buffer [31] . Hemoglobin in the blood is mainly responsible for stabilizing the oxygen pressure in blood and the tissues [32].

In our samples, no anemic cases or controls had serum ferritin below $12 \mathrm{ng} / \mathrm{dl}$, 
however ,5 cases (12.5\%) had level below 20 ng /dl "low iron stores "( 33\}. The same percentage of low serum ferritin in asthmatics was found by Fida et al 2013(6). Positive correlation of serum ferritin with $\mathrm{Hb}$ and its -ve correlation with TIBC support diagnosis of IDA. As mentioned before serum ferritin is acute phase reactant and some rise in asthma case is expected (17) but it still highly significant lower in cases than controls. Reevaluation of lower limit of lower serum ferritin for diagnosis of IDA may be required especially when acute phase reactant is expected . Agrawal A et al 2014 (20) did not find significant difference between wheezy children and controls regarding IDA though he found children with iron deficiency anemia were at a higher risk of wheeze. They attributed these results because of taking serum ferritin below $12 \mathrm{ng} / \mathrm{dl}$ as a criterion for diagnosis of IDA. This criterion of serum ferritin below $12 \mathrm{ng} / \mathrm{dl}$ may limited the number of IDA diagnosed cases among his wheezing cases

In our study significant difference in $\mathrm{Hb}$, RBCs, TIBC, and serum ferritin regarding severity of attacks using one-way ANOVA table (4). This difference is still significant between mild and moderate cases (lower $\mathrm{Hb}$ ,RBCs , ferritin and higher TIBC " $\mathrm{P}$ was 0.000 , 022 and 0.005 respectively ) and not significant between moderate and severe cases ." data not shown". Also positive correlation was found between serum ferritin and duration of admission. In agreement with these findings, Eissa SA et al 2016 found positive correlation between $\mathrm{Hb}$, serum ferritin and pulmonary function tests (22) Also Nwaru et al 2014 found positive correlation between maternal serum in ferritin $1^{\text {st }}$ trimester and pulmonary function and development of wheezing at $10 \mathrm{ys}$ of age (16). Pulmonary function testes is expected to correlates negatively with severity of attacks and duration of admission . We could not assess pulmonary function in our cases because of age limitation. Serum iron did not show relation to severity of attack or duration of admission. This finding is expected because serum iron is not reflection of body iron state
(17). However, umbilical cord iron concentration was found to be inversely associated with childhood wheeze up to 42 months of age (34). Anti allergic role of iron in asthma was demonstrated in experimental animals by Maazi $H$ et al 2011 and Hale LP et al 2012 ,iron was found to decreased eosinophil infiltration, mast cell stabilization and decreased cytokines production $(12,35)$. In US women higher iron stores, as represented by higher serum ferritin > 75ng $/ \mathrm{ml}$, were associated with a lower prevalence of asthma and asthma attacks (36). Our finding of significant lower serum ferritin in non- anemic asthmatics compared to non-anemic controls support protective role of iron against asthma and pulmonary diseases when anemia is not present. Mice with decreased iron stores while hematologic parameters (e.g. Hgb, Hct) still within the normal range had increased airway resistance (35). Other possible mechanism of protective role of iron against pulmonary diseases that it may relief pulmonary vasoconstriction (37)

Our findings have implemental role in management of asthma. Assessment of hematological, iron status in is required for possible IDA, iron deficiency in asthma cases to decrease asthmatic attacks and asthma exacerbation. IDA, iron deficiency is very common public health problem in children in developing countries ranges from 35- $90 \%$. (38) and about $64 \%$ in our localities (39). In addition, asthma is possible risk factor for IDA, and iron deficiency. Inflammatory reaction which associate asthma release hepcidin " iron regulating hormone " limiting iron absorption and utilization of stored iron . (40) As mentioned before iron may be protective against asthma in US women (36) and its administration reduced airway hyper reactivity and eosinophilia in a mouse model of allergic asthma (12). Caution must be applied during this approach in management. One of important triggering factors in asthma is infection especially URTI. Although iron supplementation reduced morbidity in children with URTI (41), other reports indicated that 
there was an increase or no change in the incidence of infectious disease $(42,43)$. Iron supplementation appeared to down regulate mast cells and decrease cytokines release .This pathway is beneficial for allergy but may be detrimental for host defense against infection (44).

Some limitations in our study are small sample size, which nearly covers one phenotype "non-atopic type" which occurs in preschool age. In addition, we studied asthmatic children during asthma exacerbation. Larger studies is required to cover all pediatric ages and all asthmatic phenotypes including atopic phenotype, which present in older age group. Further studies is required to include asthmatic children who are in quiescent "controlled " to allow comparison with those in exacerbation " acute attack ". We used serum ferritin as reflection of body iron state. Serum ferritin is acute phase reactant and is expected to be increased during inflammatory reaction, which accompany asthmatic attacks, however similar studies used serum ferritin as marker of iron state, and serum ferritin was higher in controls without expected inflammatory reaction compared to asthmatics. Another markers of iron state, serum transferrin receptor (sTfR) which is a measure of tissue iron need and $\mathrm{A}$ sTfR-F Index, which estimates total body iron correlated better with pulmonary function than ferritin but ferritin correlated better as protective against asthma at certain threshold in US women (36) . Further studies using these markers may give more valuable information about the protective role of iron against asthma and pulmonary diseases.

Conclusions we investigated IDA, serum iron, TIBCs, serum ferritin in children with bronchial asthma. We found asthmatic children have higher risk of IDA . IDA is more prevalent in asthmatic compared to healthy controls. Asthmatic children have risk of iron deficiency even when they are not anemic compared to healthy children. IDA and iron deficiency correlated with severity of asthmatic attacks. Screening of asthmatic children for IDA and iron deficiency may be helpful in management.
Timing of treatment with iron needs further investigations.

\section{5- REFERENCES}

1- Liu AH, Covar RA, Spahn J D and Sicherer SH. Childhood Asthma, In Nelson Textbook of Pediatrics, 20 $0^{\text {th }}$ ed. Copyright (C) 2016 Chapter 144 :1095-1115,eds.. Kliegman R . efeciency M,. Stanton B. F, St Ge me III JW and Schor NF, Saunders, An Imprint of Elsevier

2- Forno E and Juan C. Celedón JC. Predicting Asthma Exacerbations in Children Curr Opin Pulm Med. 2012: 18(1): 63-69

3-Hijazi N, Abalkahil B, Seaton A. Diet and childhood asthma in a society in transition: a study in urban and rural Saudi Arabia. Thorax 2000; 55(9): 775-779

4- Ramakrishnan k and Borade A. Anemia as a risk factor for childhood asthma .Lung India. 2010 ,27(2): 51-53.

5. Ramakrishnan $\mathrm{K}$ and Harish PS. Hemoglobin level as a risk factor for lower respiratory tract infections. Indian J Pediatr. 2006;73:881-3

6- Fida NM, and Kamfar HZ.Is iron Deficiency Anemia a Risk Factor in Asthmatic Children? Department of Pediatrics, Faculty of Medicine King Abdul-Aziz University, Jeddah, Saudi Arabia JKAU: Med. Sci.2013 , 20 ( 1): 3-14

7-.Triche EW, Lundsberg LS, Wickner PG, Belanger K, Leaderer BP and Bracken MB. Association of maternal anemia with increased wheeze and asthma in children Ann Allergy Asthma Immunol. $2011,106(2)$ : 131-139.

8- Drury KE, BA; Schaeffer MII BS; Jonathan I. Silverberg J I, MD, PhD, MPH . Association Between Atopic Disease and Anemia in US C children JAMA Pediatr. 2016;170(1):29-34.

9- Housset BCR .Seances Soc Biol Fil. Free radicals and respiratory pathology1994;188(4):321-

10- Vlasić $Z^{1}$, Dodig $S$, Cepelak I, Topić RZ, Zivcić J, Nogalo B, Turkalj MJ. Iron and ferritin concentrations in exhaled breath condensate of children with asthma 2009 ,46(1):81-5.

11-Vanderford DA, Greer PK, Sharp JM, Finberg KA, Chichlowski M, et al. (2010) Alopecia in IL-10-deficient mouse pups is c-Kitdependent and can be triggered by iron deficiency. Exp Dermatol 19: 518-526...

12-Maazi H, Shirinbak S, Bloksma N,M. C. Nawijn MC and van Oosterhout A.J.M.Iron administration reduces airway hyper-reactivity 
and eosinophilia in a mouse model of allergic asthma Clinical and Experimental Immunology, 2011, 166: 80-864

13- Hale LP , Kant EP, Greer PK and Foster WM . Iron supplementation decreases severity of allergic inflammation in murine lung PLOS ONE www.plosone.org 1 September 2012: (7 ) 9 ,e45667

14- Holwill WU, S. D. J. \& and Oliveira D. B. G. Desferrioxamine modulates chemically induced $\mathrm{T}$ helper 2-mediated autoimmunity in the rat Clin Exp Immunol 2004; 135 :194-199

15-Nwaru B, Hayes H, Gambling L,Craig LCA, Allan K, Prabhu $\mathbf{N}$ et al. An exploratory study of the associations between maternal iron status in pregnancy and childhood wheeze and atopy British Journal of Nutrition (2014), 112, 20182027

16-Lanzkowsky P. Classification and Diagnosis of Anemia in Children, InManual of Pediatric Hematology and Oncology $5^{\text {th }}$ ed. Copyright (C) 2011 chapter 1:1-12 ed Lanzkowsky P ,Academic Press is an imprint of Elsevier 32 Jamestown Road, London NW1 7BY, UK

17-Lanzkowsky P. Classification and Diagnosis of Anemia in Children, In:Manual of Pediatric Hematology and Oncology $5^{\text {th }}$ ed. Copyright (C) 2011 Appendix 1 :971 Table A1-4 Red Cell Values at Various Ages: Mean and Lower Limit of Normal (-2 SD)Ed. Lanzkowsky P,Academic Press is an imprint of Elsevier 32 Jamestown Road, London NW1 7BY, UK

18- Gupta MP, Perrine CG, Mei $Z$ and Scanlon KS. Iron, Anemia, and Iron Deficiency Anemia among young children in the United States nutrients 2016, $\quad 8, \quad 330$ .w.mdpi.com/journal/nutrients.

19- El-Sayed WA, and Amer ER ,Serum 25-OH vitamin D In Children With Bronchial Asthma ,Pediatric \& clinical pathology, departments banha teaching hospital Z.U.M.J.2014,20: (1) ,119-126.

20- Agrawal A, Gupta R, Sodhi KD, Raghav V Is Iron Deficiency Anaemia, a risk Factor For Wheeze Associated Respiratory Tract Infection in Children? J. Nepal Paediatr. Soc. 2014, 34:( 3) ,195-199

21- Bener A, Ehlayel SM and Hamid Q :The impact of anemia and hemoglobin level as a risk factor for asthma and allergic diseases Indian $\mathbf{J}$ Allergy Asthma Immunol 2015;29:72-8.
22- Eissa SF, Mohammad AA , Ibrahim SA, Abd-Elgwad ER, Soliman NSA Iron deficiency anemia as a risk factor in childhood asthma Egyptian Journal of Chest Diseases and Tuberculosis (2016) 65: 733-737

23- Lemer NB : Anemia of chronic disease In In, Nelson Textbook of Pediatrics, 20 ed. Copyright (C) 2016 Chapter 451: 2316 ,eds.. Kliegman R . M, Stanton B. F, St Geme III JW and Schor NF, Saunders, An Imprint of Elsevier

24- Triche EW, Association of maternal anemia with increased wheeze and asthma in children Ann Allergy Asthma Immunol. 2011 February; 106(2): 131-139

25- Spycher BD and Kuehni CE: Asthma phenotypes in childhood: conceptual thoughts on stability and transition Eur Respir J 2016; 47: 362-365

26- McLean E, Cogswell M, Egli I, Wojdyla D, de Benoist B. Worldwide prevalence of anaemia, WHO Vitamin and Mineral Nutrition Information System, 1993-2005. Public Health Nutr. 2008, 23:1-11

27- Nwaru BI, Hayes H, Gambling L, Craig LC, Allan K, Prabhu N, et al. An exploratory study of the associations between maternal iron status in pregnancy and childhood wheeze and atopy. Br J Nutr 2014;112:2018- 27

28- Jaime-Perez JC, Herrera-Garza JL, G-A D. Sub-optimal fetal iron acquisition under a maternal environment. Arch Med Res. 2005; 36:598-602.

29- Hay G, Refsum H, Whitelaw A, Melbye EL, Haug E, Borch-Iohnsen B. Predictors of serum ferritin and serum soluble transferrin receptor in newborns and their associations with iron status during the first 2 y of life. Am J Clin Nutr. 2007; 86(1):64-73.

30-Stern DA, Morgan WJ, Wright AL, et al.: Poor airway function in early infancy and lung function by age 22 years: a non-selective longitudinal cohort study. Lancet: 2007, 370, 758-764.

31- Ganong WP. Gas transport between the lung and the tissues. In: Review of Medical Physiology, 22 nd ed. New York: McGraw Hill, 2005. 666-669.

32- Guyton AC, Hall JA. Effect of hemoglobin to buffer the tissue PO2. In: Text Book of Medical Physiology. $11^{\text {th }}$ ed. Philadelphia, PA USA: Saunders, 2006:507-508. 
33- Roy CN, Enns CA. Iron homeostasis: new tales from the crypt. Blood 2000; 96(13): 4020-4027.

34-. Shaheen SO, Newson RB, Henderson AJ, et al. Umbilical cord trace elements and minerals and risk of .early childhood wheezing and eczema. Eur Respir J 2004, 24:292-297.

35- Hale LP, Kant EP, Greer PK,W. Michael Foster WM Iron Supplementation Decreases Severity of Allergic Inflammation in Murine Lung PLOS ONE | www.plosone.org September 2012 | Volume 7 | Issue 9 | e45667

36- Brigham EP, McCormack MC, Takemoto CM, Matsui EC: Iron Status is Associated with Asthma and Lung Function in US Women. PLOS ONE DOI:10.1371/journal.pone.0117545, 2015, 17:112.

37- Rhodes CJ, Wharton J, Howard L, Gibbs JS, Vonk-Noordegraaf A, et al. Iron deficiency in pulmonary arterial hypertension: a potential therapeutic target. Eur Respir J 2011, 38 (6): 1453-1460.

38-. Lutter CK, Iron Deficiency in Young Children in Low-Income Countries and New Approaches for Its Prevention J. Nutr. , 2008, 138: 2523-2528.

39-Al Ghwass MM, Halawa EF, Sabry SM, Ahmed D. Iron deficiency anemia in an Egyptian pediatric population: a cross-sectional study. $\underline{\text { Ann }}$ Afr Med. 2015 ,14(1):25-31

40-Lee P, Peng H, Gelbart T, Wang L, Beutler E Regulation of hepcidin transcription by interleukin-1 and interleukin-6. Proc Natl Acad Sci USA 2005, 102:1906-1910.

41- de Silva A, Atukorala $S$, Irangani and Ahluwalia $\mathbf{N}$ :Iron supplementation improves iron status and reduces morbidity in children with or without upper respiratory tract infections: a randomized controlled study in Colombo, Sri Lanka Am J Clin Nutr 2003;77:234-41.

42- Murray AEJ, Murray AB, Murray MB, Murray CJ. The adverse effect of iron repletion on the course of certain infections. Br Med J 1978; 2:1113-5.

43- Berger J, Dyck JL, Galan P, et al. Effect of daily iron supplementation on iron status, cellmediated immunity, and incidence of infections in 6-36 month old Togolese children. Eur J Clin Nutr 2000; 54:29-35.

44- Malaviya R, Ikeda T, Ross E, Abraham SN Mast cell modulation of neutrophil influx and bacterial clearance at sites of infection through TNF-a. Nature 1996, 381: 77-80. 